\title{
Reconsidering identity: the ethnic and political dimensions of hybridity among majority and Turkish youth in Germany and England ${ }^{1}$
}

\author{
Daniel Faas
}

\begin{abstract}
Sociological research has hitherto largely focused on majority ${ }^{2}$ and minority ethnic identities or citizenship identities. However, the social connections between youth are not simply ethnic dynamics but also political dynamics involving citizenship categories. This article argues that in postmodern societies, it is important to reconsider the ways we think about youth identities. Drawing upon qualitative data from a study into the political identities of majority (German and British) youth and Turkish youth, educated in two Stuttgart and two London secondary schools, the research found that fifteen-year-olds had no singular identity but hybrid ethnonational, ethno-local and national-European identities as a result of governmental policies, their schooling and community experience, social class positioning, ethnicity and migration history. In working-class educational contexts, many majority and Turkish youth privileged the ethnic dimension of hybridity whereas majority and Turkish youth in the two middle-class dominated schools emphasized the political dimension of hybridity. The article demonstrates that social class and schooling (e.g. ethos and peer cultures) have a considerable role to play in who can afford to take on the more hybridized cosmopolitan identities on offer.
\end{abstract}

Keywords: Identity; hybridity; Turkish youth; schooling; social class; citizenship

\section{Introduction}

Today, with national identities being challenged by globalization and migration, there has been increasing attention on hybrid identities. ${ }^{3}$ The notion of a European political identity as complementary to national identities has been prompted by both the Council of Europe and the European Commission during the past two decades. In response, there have been a range of youth studies dealing with political or citizenship identities (e.g. Chisholm and du Bois-Reymond 1995; Barrett 1996; European Commission 1997, 2001; Convery 
et al. 1997; Cinnirella 1997; Osler and Starkey 2001). Barrett (1996), for example, adopted a social-constructivist viewpoint observing a shift in selfcategorizations between the ages of six and ten. By ten years of age, students tended to categorize themselves as Europeans as well as English. Convery et al. (1997) adopted a more post-positivist stance arguing that British students experienced discomfort with dual identities due to a lack of debate about local, national and supranational levels of solutions whereas Dutch, Spanish and Italian students scored equally high on both European and national identity. Cinnirella (1997), a social psychologist, found that there was a tendency amongst Italian students to perceive Italian and European identities as compatible, in contrast to the British respondents.

At the same time, there has been a phletora of research into majority and minority ethnic identities (e.g. Mac an Ghaill 1988, 1999; Dyer 1997; Sewell 1997; Nayak 1999; Tizard and Phoenix 2002; Youdell 2003; Byrne 2006). Mac an Ghaill (1988), for instance, in his ethnography of the schooling of African Caribbean and Asian youth, argued that there was no collective African Caribbean or 'black' identity but 'black' subcultural identities. In a later study, Mac an Ghaill (1999) employed post-structuralist notions of hybrid identities investigating notions of 'race' and racism among white male youth in England. He found that there are a range of contradictory ' white' identities which are located differently in discourses of race, racism and culture. Nayak (1999) also engaged in the discourses on 'whiteness'. His study explored how contemporary youth in Newcastle-upon-Tyne experience 'whiteness' and concluded that the identities of the majority need to be deconstructed with as much vigour as those of minority groups to avoid any future 'white backlash'. Tizard and Phoenix (2002) departed from essentialist and binary oppositions of 'black or white' and argued that bipolar constructions of 'black and white' have been responsible for notions that people can be 'between two cultures' and denials that it is possible to have identities which are 'both/and', rather than 'either/or' (Tizard and Phoenix 2002: 5f.). Their finding that youth of mixed 'black and white' parentage identified as mixed 'has partly been made possible by new ways of thinking of identities - as fluid, multiple and dynamic' (Tizard and Phoenix 2002: 54).

These studies, interesting and significant as they are, often miss the ways in which majority and minority ethnic identities and citizenship (political) identities intersect, which is the main focus of this article. ${ }^{4}$ I contend that contemporary identities have both ethno-religious and political connotations, which is why it is important to adopt a more comprehensive approach not just to the study of migrant youth identities but youth identities in general.

\section{Research methodology}

The article draws on data from a larger project, conducted in 2004, which examined how differently located groups of young people construct their 
identities (Faas 2007a; 2008a). I focused on England (old immigration host with a multicultural vision) and Germany (old immigration host with a monocultural vision), two countries which are powerful economic and political players in Europe but have put rather different emphases on issues of national identity, migration-related diversity, European integration and globalization. With the help of local authorities, I selected two boroughs in Stuttgart and London on pragmatic grounds - including proximity to Cambridge and my home town of Pforzheim - and with a similar interest in European and multicultural issues. I then formally approached two German and two English schools with comparable achievement levels, inner-city locations and socioethnic intake; and met with the liaisons once prior to the fieldwork. A majority of interviewees at Millroad School ${ }^{5}$ in London (69.2 per cent) and Tannberg Hauptschule in Stuttgart (56.8 per cent) had skilled and unskilled parents whereas more than half of fifteen-year-olds at Darwin School (57.8 per cent) and Goethe Gymnasium (54.2 per cent) had professional middle-class and routine non-manual parents. However, around one quarter of Turkish students at both Goethe (28.6 per cent) and Darwin (23.5 per cent) had skilled and unskilled parents compared with just one out of ten majority youth. This indicates that the Turkish sample at Goethe and Darwin is somewhat 'less middle class' than the group of majority youth and lends weight to other factors affecting identity formation, including school dynamics (e.g. ethos, peer cultures).

Questionnaires were distributed in the opening stages of the project to 202 students in the two German schools and 208 students in the two English schools. I handed out the questionnaires myself to all the classes and assured students that all responses would be kept confidential. However, there was an issue of consent here as the students were asked by myself and the teacher who was present in the classroom at the time to fill in the questionnaire and thus did not have much of a chance to object. There was no obvious dissent from students to participate. This resulted in all distributed questionnaires being completed and returned. The aim of the questionnaire was to obtain broad insights into how students positioned themselves in relation to ethnic and political identities. The first set of questions was mainly concerned with biographical details. The next part of the questionnaire was designed under the heading citizenship, requiring participants to position themselves as citizens. The following two sections dealt with the nation-state and Europe and asked students about their images of, and associations with, each of these societies. Since questions on multiculturalism were potentially more sensitive for the students than those on the nation state and Europe, I placed them towards the end of the questionnaire. However, it was not clear what students actually meant by 'being British', 'Turkish' or 'European' and how they constructed their identities which is why most of the collected data was qualitative. 
The main sampling technique used was purposive sampling to ensure a gender and ethnic balance in each school. Regarding the focus groups and individual student interviews, I worked with the teachers to help me identify students who can express themselves sufficiently well in German/English. This meant of course that I did not tap the opinions of the introverted, passive or shy students. However, I asked for students from all ability groups to be included in the sample. In the event, I conducted six focus groups of four to five students in each school (single-sex and mixed majority and Turkish youth) and I also interviewed eight students in each school (two boys and two girls from each of my ethnic groups). The main reason for interviewing majority and Turkish youth separately was that in an ethnically mixed group there would be no possibility of tapping the different discourses majority and Turkish students employed in their identity construction processes. When designing the focus group interviews, I decided to use multiple conceptual themes associated with identity - positioning, integration and politics. The notion of positioning related to the range of categories including national, ethno-religious and European that students drew upon to define their identity. Integration was defined as the acceptance of people in a society and it was thus helpful to look at interethnic friendships and social inclusion. The notion of politics related to young people's opinions about how societies are governed and who holds the power within these societies. The questions in the focus group schedule, as well as the sequencing, were similar to those in the individual student interviews. However, while the focus group method used group dynamics to define terms such as 'citizen', 'Europe', 'England', 'being English and British', the individual interviews included more personal questions on the role of the family. I also interviewed sixteen teachers (the head, citizenship coordinator, the head of geography and the head of religious education) to gain insights into the role schools play in forming identities. All interviews were tape-recorded, transcribed and then analysed using a broadly inductive approach whereby the thematic categories and findings emerged from the deconstruction of the multiple meanings of these transcripts.

This article focuses mainly on the twenty-four student focus groups and thirty-two individual student interviews to show how the ethnic and political dimensions of identity intersect. The interviewer, who is the author of this paper, is a native-speaker of German and fluent in English and relatively young which, in terms of age at least, resulted in a fairly balanced power relation during the interviews. The strategies I used to be a non-threatening 'other' included introducing myself as someone who would like to learn more about other cultures and ways of thinking about people and society. I also decided not to dress too formally so that students were not put off by the image of having a teacher-like adult in the room. Despite these strategies, there was a possibility that the respondents constructed their identities in response to my own identity (e.g. adult, German, middle class) and the questions I was asking 
of them. It was difficult of course to determine the extent to which my own identity may or may not have interacted with the interviewees' selfperceptions. The choice to focus on Turkish youth makes this article particularly topical because (a) it is fascinating to explore the shifting identities of Turkish students as Turkey gets politically closer to Europe (Faas 2007b); (b) this is the only minority ethnic group with sufficiently large numbers in both German and English schools; and (c) this is a particularly under-researched community. Before I move on to analyse the ethno-political dimensions of youth identities, I shall briefly consider the main concepts underpinning my analysis: identity and hybridity.

\section{Theorizing identity}

There are various ways in which identity has been conceptualized, including social constructivist approaches (e.g. Barrett 1996; Cinnirella 1997), which draw upon socialization theories such as social identity theory and selfcategorization theory, and post-structuralist approaches (e.g. Mac an Ghaill 1999; Nayak 1999). The former assume that the nature of the person who is interacting with the world is 'a complete whole', a non-fragmented self whereas, in the latter, the subject is discursively constructed by the social context such as government policies and school approaches. An increasing number of contemporary writers, including Brah (1996), Skeggs (1997), Nayak (1999) and Rassool (1999) appear to be using a post-structural theoretical and methodological approach. Theorists like Foucault $(1980 ; 1988)$ and Derrida (1981) believe that there is no individual ' $\mathrm{I}$ ' that interacts with the social context but that the only way an 'I' comes to exist is through the productive power of discourse. Secondly, post-structuralist approaches allow for multiple categories of identity and, most importantly, these multiple shifting identities do not have to be reconciled. Thirdly, a post-structuralist framework challenges the idea of a single monolithic truth and identity (as opposed to the Enlightenment and modernity) and, finally, the use of mainly qualitative methods allows young people to conceptualize their identities in their own words.

Drawing upon post-structuralist notions of multiple, fragmented and discursively produced subjects, Brah (1996: 124) argued that identity may be understood as

that very process by which multiplicity, contradiction, and instability of subjectivity is signified as having coherence, continuity, stability; as having a core (...) that at any given moment is enunciated as the ' $\mathrm{I}$ '.

Brah's conceptualization of identity leaves open the possibility for individuals to feel strongly about their identities, to construct subjects that can be 'spoken'. Hall (1996: 5) goes further to maintain that identity production also involves 
processes "which attempt to "interpellate", speak to us or hail us into place as the social subjects of particular discourses'. Butler (1997), among others, suggested that within a post-structuralist framework, identities can be understood as 'performed'. The notion of performativity, relating to young people's negotiations of their identities, was important for the design of the study because performative suggests that identities are a continual establishment and articulation of binaries. The linking of techniques of the self (Foucault 1988) and performance opens up an exploration of the ways in which the social context (e.g. schools, government policies) mediates how subjects deal with the lived realities of specific institutional locations (Mac an Ghaill 1999).

The concept of identity/identities, meaning the communities young people feel they belong to, also underpins the conceptualization of this paper. In contrast, the notion of identification (Skeggs 1997) refers to the reasons and discourses students employ to identify with a particular community. It is also crucial to differentiate between hybrid (e.g. Hall 1992; Tizard and Phoenix 2002) and hyphenated identities (e.g. Caglar 1997). Hybrid identities, according to Bhabha (1990), can be understood as 'mixed' identities which emerge as a result of the interconnections between diasporic or ethnic affiliations and political identities such as 'being British'. In contrast, the notion of hyphenated identities, as understood by Caglar (1997), relates more to territorial or political identities, such as African-American, rather than the emergence of a new identity. Hyphenation implies that an individual continuously mediates between two disparate cultures and territories. Arguably, the fact that many young people constructed their identities along ethnic and political dimensions, rather than mediating between two territories, suggests that the notion of hybrid identities is more accurate when analysing contemporary youth identities. I contend that at a time of increasing globalization and migrationrelated societal transformations, it is useful to consider the postmodern subject as having fluid identities. Within this framework, young people (re)negotiate their identities within the world in relation to the available discourses and are not born into it with a static identity. The next sections reveal how fifteenyear-olds in two German and English secondary schools draw upon both ethnic and political dimensions in their identity formation processes.

\section{Contemporary youth identities in Germany}

Germany was a founding member of the European integration project and, as a result, schools and the curriculum throughout the 1980s and 1990s were used to construct a 'Europeanized national identity' (Risse and Engelmann-Martin 2002). Building on various earlier initiatives to implement a European dimension (e.g. the 1978 and 1990 'Europe in the Classroom' documents), in 2008, the Standing Conference of the Ministers of Education published the revised 
document 'Europe at School' (Europabildung in der Schule). It stated that the goal of education must be 'to awaken in young people the consciousness of a European identity; to prepare them to be aware of their responsibilities as citizens of the European Community; and to promote mutual learning with young foreigners to foster the ability to feel mutual solidarity' (Kultusministerkonferenz (KMK) 2008: 6f.). In 1992, the KMK identified foreign languages; political and cultural education; school exchanges as well as teacher exchanges as particular areas for development. Several German federal states subsequently overhauled their school curricula. However, despite their promotion of a European dimension, schools were also keen to emphasize in their civic education curricula that Germany is a democracy.

At the same time, Germany was reluctant to respond to the presence of 'guest workers' and fitting minority ethnic communities like the Turkish Muslims into its Europeanized concept of nationhood. 'Integrating guest worker children' into the German school system while preparing them for a possible return to their country of origin, known as 'foreigner pedagogy' (Ausländerpädagogik), was the guiding principle of education in the 1960s and early 1970s. Despite mass immigration, it was not until the 1980s that a concept of multicultural education was developed in response to the presence of 'guest worker children' and it was only in 1996 that the KMK published the guideline 'Intercultural Education at School' (Interkulturelle Bildung und Erziehung in der Schule), stating that the federal states should 'overhaul and further develop their curricula and guidelines of all subjects with regard to an intercultural dimension; develop teaching materials which address intercultural aspects as an integral part of education; and only allow textbooks that do not marginalize or discriminate against other cultures' (KMK 1996). Most recently, policymakers have emphasized integration around German language learning and the government has organized several (youth) integration summits as well as Islam conferences with a view of fostering interaction and intercultural dialogue (see Faas 2008b). This sets the context for young people's responses. Although the two schools were in the same policy framework, the identity formation processes were rather different.

\section{Turkish German and Swabian German ${ }^{6}$ identities at Tannberg Hauptschule}

Tannberg Hauptschule, located in a predominantly working-class residential area of Stuttgart, mediated national identities through a dominantly European and arguably, at times, a Eurocentric approach where some teachers referred to the Christian roots of Germany and Europe and established a racialreligious hierarchy which privileged the Christian cross over the Muslim hijab and thus did not consider Turkish people part of the European project; others occasionally spoke German with a foreign accent (Ausländerdeutsch). While 
eating with the students in the canteen, I witnessed cultural insensitivity amongst some teachers towards Turkish Muslim students. On that particular day, there was pork and beef sauce available for the students and the teachers on duty told a male German student who wanted to help himself to some beef sauce that this is 'Muslim sauce' (Moslemsoße) and that he should rather take some 'non-Muslim sauce' because 'you will get impotent from [the Muslim sauce]'. As a result of the Eurocentric environment and the mainly workingclass background of Tannberg students, neither the German nor the Turkish respondents saw themselves as 'European'. Europeanness, for these students, was not separate from the concept of being German. Most of the Turkish fifteen-year-olds argued that they felt European 'because I live here in Germany (...) and Germany is part of the EU'. In contrast, a group of four Turkish boys claimed that 'I don't think I feel part of Europe (...) I feel more Turkish'. Similarly, the majority of German youth also only felt European 'because Germany is part of the EU and Europe'. Only a small minority of respondents felt proud about their German identity, saying 'I feel German; I don't know what all these countries have in common'.

In contrast, most Turkish interviewees seemed to identify with Germany. Most claimed that Germany was more important than Turkey. The following quotation shows the dilemma Sema and Zerrin face as a result of their hybridized ethno-national (i.e. Turkish German) identities. In Germany, they are positioned as 'foreigners' and in Turkey people refer to them as Germans, which is precisely what Auernheimer (1990:201) referred to as individuals acquiring a marginal identity and positioning in relation to both cultures of reference:

DF [Daniel Faas]: Where do you feel you belong to?

SEMA: As a citizen I feel I belong to Germany. But when people ask me, I mean, when I am here then people call me 'foreigner'. When I go to Turkey, they call me 'German' there.

ZERRIN: Yes, I don't feel I belong to anything. I don't think that I am German and I don't think that I am Turkish. I don't know. When I go to Turkey, then they say 'Oh, look at the German'; and here I am a foreigner. Great. So, who am I? Where do I belong to?

SEMA: As a citizen, I can say I belong to Germany.

ZERRIN: I can say that I'm a German citizen but I'm not German. German citizen, I think, means that I have to adapt to this country, I try to adapt myself, and then I think about the laws and everything. I know a lot more about Germany so that I am a German citizen, but I'm not German. But, I'm not Turkish either.

SEMA: I know Germany better than Turkey. I could never ever imagine living in Turkey. 
Zerrin's questions 'Who am I? Where do I belong to?' highlight the ongoing process of identity formation, the struggle between 'being a German citizen' which is based on residence and 'being German' which is based on blood and 'race'. During the interview, Sema further justified her feelings saying that she could not speak Turkish that well and that she did not have any friends back in Turkey. Also, she preferred the freedom of Western societies to dress however you wanted and distanced herself from those 'typically Turkish women who just sit around all day long not doing much apart from knitting and gossiping about others'.

While the group of Turkish students constructed their identities around Turkish and German communities, they could only relate to the regional Swabian identity in a quite painful and unentitled way, partly because of their unfamiliarity with the dialect and traditions. Swabia was an administrative region and is today still used in popular culture as an ethnic identity for those living in the Württemberg part of the south-western federal state of BadenWürttemberg that includes Stuttgart. However, as a result of being born in Stuttgart, some Turkish students, notably the group of Turkish girls I interviewed, were able to imitate the Swabian dialect fairly well, saying 'Ah, des koscht du jetzt net mache, gel' (Oh, you can't do this now, can you?). The use of the word 'gel' was particularly suggestive of the girls' familiarity with the Swabian dialect. Generally, however, Turkish youth at Tannberg Hauptschule argued that 'I feel more part of Stuttgart than Baden-Württemberg'. For young Turkish people who were born in Stuttgart, but not fully exposed to the Swabian culture, this was a rather distant community.

The notion of 'being Swabian' was then linked by some of the German youth with concepts of blood and family which, arguably, made it very difficult for the group of Turkish students to relate to as their families were born in Turkey. The following passages show that Ralf and Verena gave their Swabian identity priority over their German:

DF: To what extent do you see yourself as Swabian or German?

RALF: Swabian, rather Swabian, yes. Because there are also those in the East and I am rather Swabian. My mum was born here, and my dad, and me too and we are totally a Swabian family, yes. [... ]

VERENA: I was born and grew up in Stuttgart, in Baden-Württemberg, and when I was younger I always spent the day at my grandma's place, 'cos my mum was at work, and she raised me like a Swabian, so.

However, there were also those German interviewees, such as Sebastian, who argued that 'I feel first German and then Swabian. I have a German passport and not a Swabian one'. Despite varying emphases on local, regional and national identities, what emerges from these data is that most of the German 
respondents at Tannberg Hauptschule employed Swabian German identities, indicating the complex nature of youth identities.

\section{German European identities at Goethe Gymnasium}

Like Tannberg, Goethe Gymnasium, promoted European values but this time alongside rather than instead of multicultural values. Socio-cultural and ethnic differences were mediated in this school (located in a mainly middle-class area in the same inner-city Stuttgart borough) through notions of tolerance, liberalism and a strong sense of community. The teachers I spoke to had a deeply ambivalent relationship towards German national identity and referred to Germany's Europeanized national identity. This submerged national identity was reflected in the school's approach of what I would call 'multicultural Europeanness' which emphasized Europe as a common bond but, at the same time, allowed individuals to keep their cultural and ethnic identities. Most youth made identification with Europe dependent on stays abroad (e.g. 'I only know Germany; if I was living in Spain for a few years, then I'd more say that I'm European ... 'cos I'd be familiar with different countries'), parental influence (e.g. 'my parents experienced a lot and tell me a lot about other countries and culture; Europe plays an important role for me too ... 'cos I'm interested in getting to know these other countries'), and the school curriculum (e.g. 'we learn a lot of European languages here in school and talking in Italian, English and French to other people makes me feel partly European'). However, in this liberal and inclusive environment, where the relationships between different communities appeared to be congenial, the young people I talked to felt positive about Europe:

DF: To what extent do you see yourself as European?

ALI: Erm, of course I'm European. Europe is very big and is getting bigger and bigger. And when Turkey joins the EU it'll be even bigger. Europe is getting more and more important to me ... 'cos of Turkey. [...]

SAMUEL: Europe, the EU, plays an important role in my life. When I go abroad it's just so simple. There are hardly any border controls and it's just getting easier and easier. The countries are not on their own anymore and are together; and there are no borders anymore, very open. [...]

MARIAM: I feel European because of the Euro. The Euro impacts on your life. I mean, in the newspaper they always talk about the Euro, Eurozone, Europe and so and I've noticed that the countries are getting closer and closer and not every country has its own policy. And the economy has grown together too. And you can travel to other countries without any problems at the borders. 
Several German students employed the image of a chain of identities arguing that Stuttgart, Baden-Württemberg, Germany and Europe were all integrated spheres and thus sites for identity formation; 'they belong together, Stuttgart is part of Baden-Württemberg and Baden-Württemberg is part of Germany and Germany is situated in Europe; it's all kind of together' and interlinked. However, there was no evidence in the data that young people felt Europeanonly or that they privileged Europeanness over (sub-)national identities. Instead, whilst Europe was part of young people's hybrid identities at Goethe, a majority of Turkish students I interviewed emphasized their German identities over and above Turkishness. They based their national identification on notions of birth and residence. Zeynep (a Turkish girl) commented that 'I'd say more German than Turkish. My dad works here, I plan to study here after school and work here as well'. Melik's remark that he felt emotionally like a Turkish Stuttgarter, a German-European Turk or a Turkish German was also suggestive of the multidimensional nature of young people's identities at Goethe Gymnasium:

DF: Where do you feel you belong to?

MELIK: I feel as a Turkish Stuttgarter so to speak, a German-European Turk or a Turkish German, but not Swabian. I don't know the Swabian culture and, I think, I'd have to be German for that with my ancestors being Swabians too.

NURHAN: You'd have to experience the culture at home but we can only see our Turkish culture and, I mean, I wouldn't want to lose that. I don't really know the Swabian way of life. Sometimes, teachers make Swabian jokes and stuff.

ISMET: (imitating the Swabian dialect) Gel.

NURHAN: We don't really know much Swabian stuff

ISMET: I'd like to add that I don't see myself as a Swabian either, more as a Stuttgarter. It's also easier to get to know the German culture, just here generally by living here, but the Swabian culture is more at home and I'm not around that. Sometimes I don't really know whether something is particularly Swabian.

NURHAN: Perhaps Stuttgart is the Swabian world and it appears to me like a German world but maybe I don't fully grasp the contrast; I should go to Berlin or so for a while and see what the differences are.

Many ethnically German students (whilst also feeling partly European) emphasized local and regional identities whilst problematizing the notion of a German identity arguing 
the only point when I'd feel German is when I speak the German language, my mother tongue. I wouldn't say I'm proud of my country which has to do with the past. If you said 'you're proud of being German' you'd be considered a right-wing nationalist or racist because of the past.

This brings us back to some of the introductory remarks, where I indicated that successive German governments mediated the concept of nationhood through the dominant European agenda and that Europe became a focal point for the organization of the German school system. As a result of this and the school's inclusive approach, fifteen-year-olds mainly seemed to employ German European hybrid identities.

\section{Contemporary youth identities in England}

Turning now to England, a country with a legacy of multicultural policies and a tendency to marginalize the idea of Europe in political and educational discourses, it seems unlikely that majority and Turkish youth have the same access to Europe as a political identity. Pragmatism rather than German idealism shaped England's relationship with Europe. There was little reason why the country should reconsider its national identity in European terms, and the processes of European integration have not seriously affected (education) policymakers. The Europeanization of British identity was undercut by the special relationship with the USA; the geographical detachment from continental Europe; and England's postwar role in the Commonwealth (Geddes 1999). Europe did not appear amongst the cross-curricular themes of the 1988 National Curriculum. The Department of Education and Science (DES) responded to an earlier Resolution of the Council of Ministers of Education on the European dimension in education, stating that the government's policies were aimed at

promoting a sense of European identity; encouraging interest in and improving competence in other European languages; and helping students to acquire a view of Europe as a multicultural, multilingual community which includes the UK. (DES 1991)

However, curriculum guidance on precisely what content and form the European dimension should assume has not matched official British concerns with multicultural issues.

Unlike Germany, England had to develop approaches to migration-related diversity after the 1948 arrival of the Empire Windrush from the Caribbean because it recruited labourers on who initially had the right to reside permanently in the host country. Although both countries initially developed assimilationist approaches (i.e. 'foreigner' pedagogy in Germany; assimilation and 
integration in England), the integrationist approach in England attempted to recognize, albeit to a limited extent, cultural and ethnic differences within the concept of Britishness. In 1988, multicultural education (unlike European education) became one of three cross-curricular dimensions of the National Curriculum. Paradoxically, throughout the 1980s, while the Conservative Thatcher governments excluded minority ethnic communities from the concept of nationhood, schools (particularly in inner-city areas) were actively engaged in developing multicultural and antiracist initiatives. Despite the recent buzzword of community cohesion, the concept of nationhood mediated through multicultural values has prevailed, setting quite a different scenario for schools and young people in England.

\section{Turkishness and Englishness at Millroad School}

Millroad School in London, located in a predominantly working-class environment, mediated national identity through the politics of cultural diversity and, in so doing, reasserted the concept of cultural pluralism which was the prevailing English educational approach in the 1970s and early 1980. During fieldwork, I observed a celebration of Turkish/Kurdishness with Turkish music and dance performances during assemblies. During lessons, I noticed that students sat along ethnic lines in almost all classrooms, with some tables of only African Caribbean students and other tables with only Turkish Kurdish students. In contrast, students in the two German schools tended to mix better and formed interethnic friendship groups. Unlike Tannberg Hauptschule in Stuttgart, the catchment area of Millroad School was at the centre of violent outbreaks in the past years between Turkish and Kurdish heroin gangs and fights between African Caribbean and Turkish youth gangs. These communal conflicts spilled over into the school and resulted in ethnic divisions between the school communities. Turkish students were mocked for their ethnicity and nationality which resulted in a strong sense of ethnic solidarity. School officials told me that they hoped that mixing staff and students and promoting intercultural awareness could tackle these community divisions, particularly between African Caribbean and Turkish students. However, given that the root of this conflict appears to be outside Millroad School, this was an ambitious agenda which attempted to disseminate 'good practice' from within the school into the local community.

The identity formation processes were deeply affected by the peer-group conflicts over which group controls the school territory. Since the Turkish students were disadvantaged both socio-economically and ethnically, this power struggle within the school boundaries was perhaps their only chance to create a sense of superiority. Many Turkish respondents (first-generation immigrants) deployed concepts of birth and pride to identify with their ethnic background, arguing that 'I feel I belong to Turkey, but, because of the 
economy of Turkey, it forces us to come to England' and 'your background's there [in Turkey] and all your grandparents, and, grandmas have been living there, so you have to follow'. In contrast, the sample of Turkish Cypriots (second-generation immigrants), in addition to their ethnic identity, drew upon the concept of residence to partially also identify with Britain. For example, Harika and Jihan seemed to have developed hybrid identities although the following discussion shows that they, too, formed an ethnic solidarity group and privileged their Turkishness:

DF: So you would say you feel you belong to both Turkey and England?

HARIKA: Yeah.

TULIP: No, I don't think so.

JIHAN: But still isn't it, .. . 'cos you were born here, yeah, and you been living here, yeah, and you go over to like Turkey and Cyprus once in your life, yeah, you don't know nothing.

TULIP: But if you're someone and your parents are Turkish, that's what you are.

NAGIHAN: No, I'm Turkish but ...

JIHAN: I didn't say you're not, but . . .

HARIKA: But you shouldn't say 'Oh, I've got nothing to do with England'.

TULIP: No, like my step-parents are English that's it, you can't say you're English or half-English.

JIHAN: Or you can say - you were born there, innit?

HARIKA: No but when someone asks you you're not going to say 'I'm English', it's just that you're going to able when something happens, when there's a football match, and let's say England's playing against Brazil or something then you would have to support England but when England's playing against Turkey you can support Turkey ... 'cos that's your race.

When I probed further, the Turkish Cypriot girls were able to differentiate between the regional English and national British citizenship levels. Notions of 'being English' were linked to concepts of birth, 'race' and whiteness whilst 'being British' was thought of as a wider and more inclusive term; 'British is like everybody', you can become a British citizen by law. Whilst the Turkish British identity emerged as an option for some second-generation Turkish Cypriot students, the first-generation mainland Turks felt Turkish-only.

Some British students in this study also tended to privilege national(istic) identities and saw themselves as English rather than British, a term they 
associated with concepts of blood and birth. For example, the following group differentiated between the generic term 'British' and more particular constructs such as 'English' or 'Scottish':

DAVE: English is more like ... specific.

BILL: Yeah, Britain's just like I mean . . . for example, you could come over to this country, be here for a certain amount of years and you'd 'become' British. But English like, you have to be born here, raised here [KEN murmurs agreement], be like one of us. So British is just a crap word really.

KEN: British is like the official name for it, and English is like what the actual people are, like.

JOHN: It's like, if you're from Scotland, people don't say 'Oh, I'm British', they'll say 'I'm Scottish' [murmurs of agreement] 'cos most people when they hear 'Oh, I'm from the United Kingdom', they think 'England', that's pretty much what most people think, they don't think 'ah, he could be from Wales, I dunno', they just think England straight away. Whereas if you say 'I'm Scottish', they don't know it's in the United Kingdom, like if you're in America or something like that.

Emma was less one-sided attempting to put herself into the position of other people, such as the press, to differentiate between Englishness and Britishness:

EMMA: English to me always sounds kind of a bit, very white, very kind of kind of racist in some ways. It's the kind of thing that the right-wing press says. Um, I think Britain has more kind of diverse and stuff connotations than English. I think English would be like a race, whereas British would be like a culture.

In contrast with national identities, the concept of Europe as a political identity did not easily fit with young people's Turkish or English identities. Turkish youth were acutely aware of their 'otherness', emphasizing their different religion, phenotype and limited power. Like the Turkish students, the British students I spoke to positioned themselves outside the notion of Europe. Being 'the odd one out that drives on the left and has the pound' as well as being 'an island off Europe' made it difficult for young people to identify with.

\section{Turkish British and English/British identities at Darwin School}

Darwin School is located in the same Inner London borough as Millroad School; however, the western part of this borough is far more affluent. Here, there were virtually no signs or reports of ethnic tensions and communal 
conflict. The school celebrated similarity rather than cultural and ethnic difference. The Darwin ethos, and indeed its curriculum, suggested that young people were encouraged to think of themselves as liberal, democratic, British citizens living in a global multi-ethnic international community. These messages were transmitted for example through citizenship education. Social class also became one of the unifying factors in this school, giving students an advantaged position within the British society. In this context, ethnicity seemed to play only a subordinate role in youth relations. Both British and Turkish students at Darwin showed a higher level of social integration (e.g. inter-ethnic friendships) compared with their peers at Millroad which allowed them to develop multidimensional identities. Turkish youth, particularly second-generation Turkish Cypriots like Safak, but also first-generation mainland Turks, identified with both Britain and their country of origin:

DF: What role would you say does your Turkish Cypriot background play in your life today?

SAFAK: Well, it plays a big part 'cos that's my origin, but I don't think of it as a big part where everything I do is revolved around that. I think ... 'cos, you know, I don't live there and I don't know people - I do know some people but they're not like the people I know here, that I like, all my friends are here, and my close family's here, so obviously I care more about them than I do distant family who I only see once a year. But it plays a big part as to who I am, because of the way,...' 'cos that's just who I am,...' 'cos I am Turkish-Cypriot, but I don't make my whole life go around that. I kind of just, I just try to stay in between and care about both things just as much, like, just as equally, but obviously that's harder 'cos I do a lot of things here, like watch British TV, that makes me learn more about England and London, than I do about Turkish, because, well, I watch Turkish TV less.

Safak tried to balance her various identities by attempting to stay 'inbetween' and care about both societies. She tried hard to keep herself equally well-informed about the two countries by watching television but she had to realize just how difficult it is 'to care about both things'. Also, Safak directly referred to notions of proximity and distance, arguing that she cares more about her close friends and family in England than about distant family members in the Turkish part of Cyprus whom she only sees once a year. This new hybridized Turkish British identity, which we only tentatively saw amongst few Turkish Cypriots at Millroad School, was also clearly expressed by the first-generation mainland Turks at Darwin School although they still saw their ethnic background to be more important to them than Britain: 
DF: Where do you feel you belong to?

TOKER: I think I'm part of Turkey, still. I think I'm part of Britain too, ... 'cos I've got a British passport.

DF: Can you explain that a bit more?

TOKER: I say Turkey . . . 'cos I was born there and I lived there for 7 years, so, that's why I think Turkey. Half of my life was there. Dunno, about Britain, ... 'cos I've got, . . .'cos I think I dunno!

DF: What are the differences between Turkey and Britain?

TOKER: The difference is England's more rich, and Turkey's poor, but I think Turkey is a much better place to live in.

DF: Why?

TOKER: Erm, dunno, people are more friendly and I like the places, erm, cities.

British fifteen-year-olds also had multidimensional identities revolving around familiar communities such as family, school and friends as well as London and England. As William put it, 'I think more locally but as we get older, wider things [e.g. Europe, world] will become more important as they affect us more'. The British students additionally provided a very useful explanation as to how these familiar identities are interlinked and why they are all partly relevant and not competing in the construction of contemporary youth identities:

ADAM: School's kind of a duty that a child has to fulfil, erm, I was born in London, which happens to be in England [they laugh], therefore I'm a citizen of London and England, and my school, which is in London, so therefore they're all kind of interlinked.

CHARLOTTE: If you don't, If you weren't in London, you wouldn't be able to go to [name of the school], if you weren't in Britain you wouldn't be able to live in London, because you can't because London's in Britain.

DF: So would you say all these things are equally important?

ALL: Yeah.

CHARLES: 'Cos you're a community inside a community inside a community.

Few students I interviewed argued that Britain is part of the EU. However, while Turkish students at Millroad employed a theme of 'us' (Turkish) and 
'them' (European) and thus put a distance between themselves and Europe, in Darwin School, mainland Turkish and Turkish Cypriot students were able to identify with Europe so long as Turkey was included in the notion of Europe. A number of Turkish Cypriot interviewees, such as Mustafa and Safak, referred to British insularity and separateness from Europe arguing that 'I am European 'cos I'm in Europe, and I'm in Britain which is in Europe and part of the European society; but I don't see myself as a European because Britain has its own kind of bubble, separate from Europe'. Mustafa and Safak's discourses were suggestive of their Turkish British identities.

\section{Discussion and conclusions}

The article has revealed that majority (German and British) youth formed, what could be called, a chain of identities. In the two German schools, they linked the local Stuttgart, regional Baden-Württemberg or Swabian, national German and European citizenship levels. However, as a result of the different prioritization of European agendas at German and English government level, these chains of identities generally did not include supranational levels in the case of majority youth in the two English schools. Turkish fifteen-year-olds, by contrast, had developed different forms of hybrid identities so that the image of a chain of identities could not be easily used with regard to them in either country. One of the most notable differences we saw was that majority youth, in both Germany and England, generally also had a regional identity (i.e. Swabian identity or English identity) whereas virtually none of the Turkish students I interviewed saw themselves as having a Swabian identity. This suggests that fifteen-year-old Turkish students in the four schools positioned themselves within, what could be called, a triangle of identities. In such a triangle, it is possible to combine all the different ethno-political identities without seeing one sphere as being integrated within the other. In fact, unlike many majority youth, most Turkish youth I interviewed perceived the regional and national identities as competing. In both the German and English sample, the Turkish fifteen-year-olds in particular perceived the regional identity as a sort of ethnic identity, meaning that you have to be born Swabian or English.

The article has further shown that the concept of hybridity worked differently in these institutional settings and was affected by a range of factors, as summarized in Figure I.

The young people placed different emphases on ethnic affiliations and political dimensions and thus produced different forms of hybrid identities. In the two working-class schools, we saw that majority and Turkish youth, and especially the male students at Tannberg, privileged the ethnic dimension of their hybrid identities. At Millroad School in London, where we saw the strongest ethnic conflict and divisive peer cultures, both English and Turkish 
Figure I: The ethnic and political dimensions of contemporary youth identities

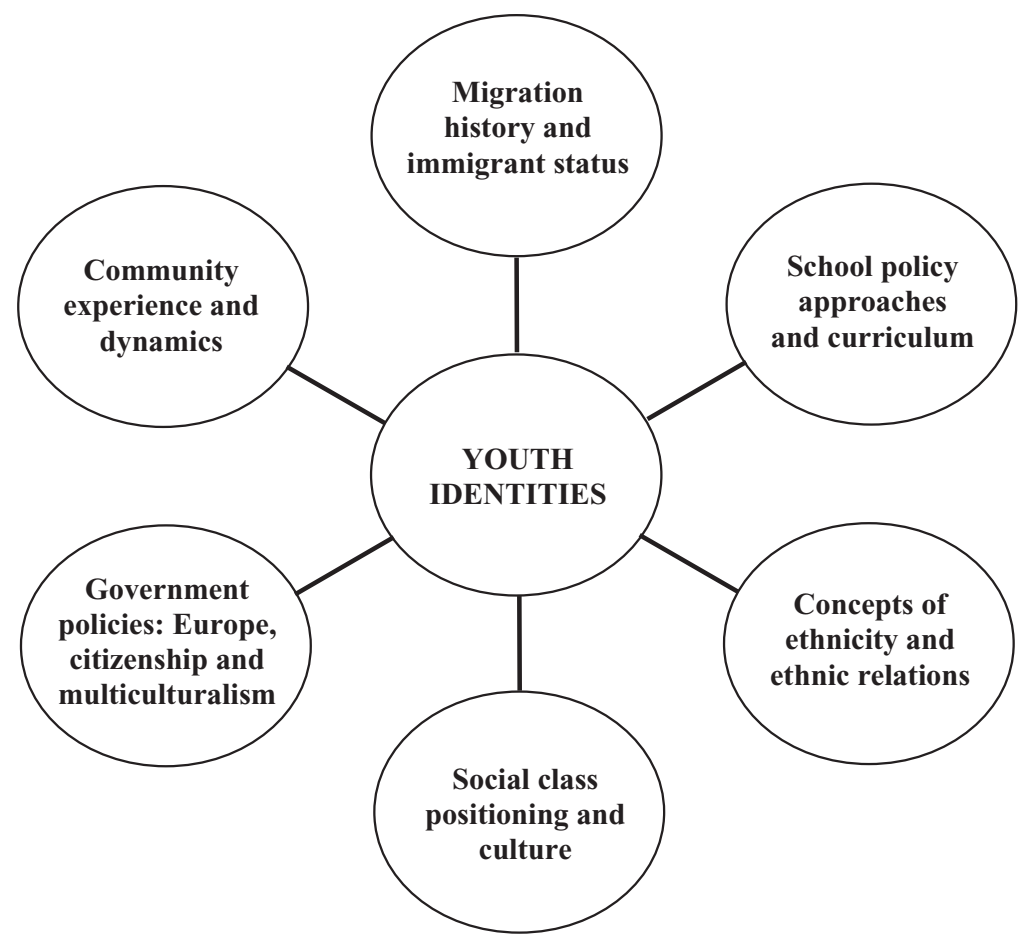

students almost exclusively emphasized their ethnic belonging (i.e. Turkishness or Englishness). In this racially charged school environment, the concept of hybridity appeared not to have been operationalized to any great extent. In contrast, in the two middle-class schools, a majority of German/British and Turkish students emphasized the political dimension (e.g. 'being British') of hybridity although some Darwinian students in the study, and first-generation mainland Turks in particular, still privileged ethnic dimensions. Although it was not possible within the scope of this article to fully analyze (the importance of) each of the individual factors affecting young people's hybrid identities, the article has unravelled the complexities of contemporary youth identities. We have seen that the dynamics between youth are not simply ethnic dynamics but also political dynamics involving categories of citizenship such as British or European citizenship. Most youth had no singular identity but employed hybrid Turkish British/German, Swabian German and German European identities.

Since many young people in this study produced different forms of hybrid identities by placing different emphasis on ethnic and political aspects of identity, the above diagram may have general relevance and could help future comparative studies of youth identity formations in other countries. The 
scheme is particularly useful in the current challenge of responding to migration-related cultural and religious diversity in a multicultural Europe. It considers the socio-economic, ethno-religious and cultural diversity of populations within Europe and beyond, both amongst national majorities and minority communities and reveals the complex scenarios we need to consider when researching identity in the twenty-first century.

(Date accepted: November 2008)

\section{Notes}

1. I would like to thank Anna Triandafyllidou for her detailed comments on an earlier version of this article as well as Madeleine Arnot and Lynne Chisholm for their conceptual input and help with my work. I also thank the British Economic and Social Research Council (Award No.: PTA030-2002-00853), the Cambridge European Trust and Clare Hall College Cambridge for their financial contributions.

2. The term 'majority' is used here to refer to the 'white' youth. Turks do not occupy a clear position in the 'white/nonwhite' divide on which current understanding of minority ethnic communities in Britain is based. In the census, they identify themselves as 'white' although Turkey is largely perceived to be a non-white country. It is not the purpose of this article to engage in this debate. Collective identities range from racial classifications (England) to policy-status identities (France) and national identities (Germany).

3. Citizenship identity is linked here with notions of nationhood and national identity.
Nationality (or nationhood) is in essence an ethno-cultural concept which binds people on the basis of a shared identity whereas the notion of citizenship identities is used as a legal-political concept in the context of this article. National identity and citizenship identity often overlap and are being challenged by globalization and migration.

4. An earlier version of this paper was presented to the British Sociological Association Conference (BSA) in London, April 2007.

5. The identities of all local education authorities, schools and students in the study were protected from outsiders by using pseudonyms.

6. Identities such as 'Turkish German', 'Swabian German', 'German European', or 'Turkish British' were intentionally not hyphenated as these are newly emerging identities which neither represent an identity crisis nor a modernist 'either/or' approach.

well and E. Lyons (eds) Changing European Identities: Social Psychological Analyses of Social Change, Oxford: Butterworth Heinemann.

Bhabha, H.K. 1990 Nation and Narration, London: Routledge.

Brah, A. 1996 Cartographies of Diaspora: Contesting Identities, London: Routledge. 
Butler, J. 1997 The Psychic Life of Power: Theories in Subjection, Stanford University Press.

Byrne, B. 2006 White Lives: The Interplay of Race, Class and Gender in Everyday Life, London: Routledge.

Caglar, A.S. 1997 'Hyphenated Identities and the Limits of "Culture" ' in T. Modood and P. Werbner (eds) The Politics of Multiculturalism in the New Europe: Racism, Identity and Community, London: Zed Books.

Chisholm, L. and Du Bois-Reymond, M. 1995 'What Does Europe Mean to Me? Dimensions of Distance and Disillusion Amongst European Students' in Circle for Youth Research Cooperation in Europe (ed.) European Yearbook on Youth Policy and Research: The Puzzle of Integration, Berlin: de Gruyter.

Cinnirella, M. 1997 'Towards a European Identity: Interactions Between the National and European Social Identities Manifested by University Students in Britain and Italy', British Journal of Social Psychology 36(1): 19-31.

Convery, A., Evans, M., Green, S., Macaro, E. and Mellor, J. 1997 Pupils' Perceptions of Europe: Identity and Education, London: Cassell.

Department of Education and Science 1991 'EC, UK and Council of Europe Resolutions in Relation to the European Dimension in Education', http://www.neelb.org.uk/ cass/languages / european/zl000171.htm\#reso lutions (accessed 12 April 2007).

Derrida, J. 1981 Positions, translated by Alan Bass, London: Athlone.

Dyer, R. 1997 White, London: Routledge.

European Commission 1997 The Young Europeans, Brussels: European Commission.

European Commission 2001 The Young Europeans, Brussels: European Commission.

Faas, D. 2007a 'The Europeanisation of German Ethnic Identities: The Case of German and Turkish Students in Two Stuttgart Secondary Schools', International Studies in Sociology of Education 17(1): 45-62.
Faas, D. 2007b 'Turkish Youth in the European Knowledge Economy: Exploring Their Responses to Europe and the Role of Social Class and School Dynamics for Their Identities', European Societies 9(4): 573-599. Faas, D. 2008a 'Constructing Identities: The Ethno-national and Nationalistic Identities of White and Turkish Students in Two English Secondary Schools', British Journal of Sociology of Education 29(1): 37-48.

Faas, D. 2008b 'From Foreigner Pedagogy to Intercultural Education: An Analysis of the German Responses to Diversity and its Impacts on Schools and Students', European Educational Research Journal 7(1): 108-23.

Foucault, M. 1980 'Truth and Power' in C. Gordon (ed.) Power/Knowledge: Selected Interviews and Other Writings 1972-77, Brighton: Harvester.

Foucault, M. 1988 'Technologies of the Self' in L. Martin, H. Gutman and P. Hutton (eds) Technologies of the Self, London: Tavistock. Geddes, A. 1999 Britain in the European Union, Tisbury: Baseline Book Company.

Hall, S. 1992 'New Ethnicities' in J. Donald and A. Rattansi (eds) 'Race', Culture and Difference, London: Sage.

Hall, S. 1996 'Who Needs Identity' in S. Hall and P. du Gay (eds) Questions of Cultural Identity, London: Sage.

Kultusministerkonferenz 1996 'Interkulturelle Bildung und Erziehung in der Schule: Beschluss der Kultusministerkonferenz vom 25.10.1996', http://www. unilandau.de/instbild/IKU/Lehre/kmkikbue. pdf (accessed 21 March 2009).

Kultusministerkonferenz 2008 'Europabildung in der Schule: Beschluss der Kultusministerkonferenz vom 08.06.1978 in der Fassung vom 05.05.2008', http://www. $\mathrm{kmk}$. org/fileadmin / veroeffentlichungen _ beschluesse/1978/1978_06_08_Europabildung. pdf (accessed 21 March 2009).

Mac an Ghaill, M. 1988 Young, Gifted and Black, Milton Keynes: Open University Press.

Mac an Ghaill, M. 1999 Contemporary Racisms and Ethnicities: Social and Cultural Transformations, Buckingham: Open University Press. 
Nayak, A. 1999 'White English Ethnicities: Racism, Anti-racism and Student Perspectives', Race, Ethnicity and Education 2(2): 177-202.

Osler, A. and Starkey, H. 2001 'Citizenship Education and National Identities in France and England: Inclusive or Exclusive?' Oxford Review of Education 27(2): 287305.

Rassool, N. 1999 'Flexible Identities: Exploring Race and Gender Issues Among a Group of Immigrant Students in an Innercity Comprehensive School', British Journal of Sociology of Education 20(1): 23-36.

Risse, T. and Engelmann-Martin, D. 2002 'Identity Politics and European Integration: The Case of Germany' in A. Pagden (ed.)
The Idea of Europe: From Antiquity to the European Union, Cambridge University Press.

Sewell, T. 1997 Black Masculinities and Schooling, Stoke-on-Trent: Trentham Books. Skeggs, B. 1997 Formations of Class and Gender: Becoming Respectable, London: Sage.

Tizard, B. and Phoenix, A. 2002 Black, White or Mixed Race? Race and Racism in the Lives of Young People of Mixed Parentage, London: Routledge.

Youdell, D. 2003 'Identity Traps or How Black Students Fail: The Interactions Between Biographical, Sub-cultural and Learner Identities', British Journal of Sociology of Education 24(1): 3-20. 